\title{
Bio-Linguistics Diversity to Balinese Language Shift in Denpasar
}

\author{
English Department, Faculty of Arts \\ UdayanaUnivesity \\ Denpasar, Indonesia \\ made_suastra@unud.ac.id \\ ketut_tika@unud.ac.id \\ seri_malini@unud.ac.id \\ sena_darmasetyawan@unud.ac.id
}

Suastra. I Made, Tika. I Ketut, Malini. Ni Luh Nyoman Seri, and Darmasetiyawan. I Made Sena

\begin{abstract}
This research aimed to discover Balinese language shift pattern in its language usage. Specifically, the research sought to comprehend and analyzed Balinese language shift based on bio-linguistics diversity that comprises of 1) contexts of Balinese language use in Denpasar, and 2) social as well as a cultural aspect that affect Balinese language shift. The research location is in Denpasar, which classified into four different regencies, they are West, East, North, and South Denpasar. Further representation of the data will be decided based upon quantitative data obtained on four regencies. Techniques of data collection will be done in the form of observation and questionnaires, with additional interview and note taking. The sample taken will be on Balinese speakers in youth and mature age. Representation and proportion of the sampling will be 50 for each location. The analysis will be done in qualitatively and quantitatively with both formal and informal method. By using the concepts of language choice, sociolinguistics, and bio-linguistics diversity, Balinese language shift model can be discovered. This language shift model will prove beneficial to the system and mechanism of language inheritance in formal and informal contexts, in the effort to maintain cultural diversity and ethnic identity of a multilingual community.
\end{abstract}

Keywords - language shift, sociolinguistics, bio-linguistics diversity, language choice.

\section{INTRODUCTION}

In the concept of sociolinguistics; language change, language shift, and language maintenance are the three significant matters that cannot be separated. This language shift refers to the language choice that will gradually shift the language preference; in contrast with language change that requires an extensive process to be classified as a change, as in Old English language that changes over hundreds of years after commonly spoken.

In the steps of language shift to immigrants, the speaker will undergo lower bilingual phase. It refers to the condition where its mother tongue language proficiency is higher than the other languages; before the equivalent bilingual step, and eventually went back to the lower bilingual stage, but in a position where the mother tongue language proficiency is lower than the other languages (Chaer, 2004: 144). Through Balinese language phenomenon nowadays, the majority of speakers (especially teenagers and children) can be classified into the lower bilingual that their Balinese language proficiency is lower than the Indonesian language. It is derived through the significant effect of Indonesian language in education level and cross-ethnic communication, as well as the little proficiency of Balinese speakers in identifying and using Balinese speech levels that only comprehended in two levels of politeness (polite and rude) from the original four levels.

By the time language shift occurs, it leads toward the majority language in a group of speakers, since this majority does not require toconsider the use of minority language. Therefore, majority language can be associated with possession of higher status and social level (Holmes, 1992: 61). In language shift, two contexts outlined it; they are the shift that occurs based on the speaker's language proficiency themselves or the change that occurs due to the impact of social policy in the speaker's community (Winford, 2003: 247). In the Balinese language, the most apparent factor in language shift is the existence of Balinese language dialects.

\section{LITERATURE REVIEW}

In his study, Bramono (2012) concluded that language shift is a phenomenon that appears in the effort of language maintenance, where language loyalty of the speaker serves 
an essential role in the process. Industrialisation and migration (urbanization and transmigration) are two of the most significant factors in language shift. Mueller (2009) research of language shift in Java to the Indonesian language, suggests that this language shift particularly occurs due to the status of Indonesian language as the language to unite the country. It aspires the use of every people; due to the rise of social level in the community that is aiming for higher status; and the development of community languages to bilingual. Cohn (2014) also suggests that Indonesian language role as a national language has developed along the decrease of local language maintenance. The impact of this movement is how Indonesia is heading towards monolingual society. This condition is strengthened regional languages shift toward the Indonesian language, where this shift occurs through each speaker; considering how the change of speakers' language choice depends on their community.

Abtahian (2016) stated that during his research in Indonesia, the method of approach in community level would prove more beneficial in the effort to discover language shift since analyzing the variation will require further study in the community language and any social factors on the speaker of that language. Social factors that discovered in Indonesia are classified into six; they are age, urbanization, development index, education, religion, and gender. These social factors cannot be combined in conducting the analysis but can be arranged in order, depending on how much it affects the language shift, starting from age, gender, social demographical factor (village and city), ethnic group, and religion. Masruddin (2013) research to Wotu (South Sulawesi) community also stated that age and mobilization serve as an essential factor that affects language shift. In sociolinguistics, bilingual and language attitude factors can also create a significant impact on the language shift. One of his findings claims that bilingual case can disappear when the speaker' parents decided not to teach two (or possibly more) languages to their child as a result of considering economy, education, a social majority, and other factors that will affect the future need of the child.

In details, Suzanne (2003) and Khadidja (2013) mentioned that discourse analysis approach to the language shift is the process of finding forms of code-switching and borrowing in the speech act. The difference of codeswitching to borrowing can be explained through speech act, where code-switching refers to a full language shift that and the return of language choice to the original language while loan relates to the process where a particular language unit has fully integrated to another word. (Grosjean, 2013: 18). Through this definition, a biolinguistics approach that has domestication characteristics (of adding language unit) can be categorized as a fully accepted form of borrowing; far from the average acceptance level.

A speaker will easily comprehend someone language or dialect when they like or respect the person; which commonly occur in a closely related group of people (Holmes, 1992: 345). Furthermore, analysis and approach to bio-linguistics diversity on language shift can discover the social aspects that affect speakers' language competence as the origin of this language change. Approach to biolinguistics diversity will be classified into two along with the development of the speakers' community; they are a distinct addition to a language unit or even the gradual disappearance of a specific language unit.

\section{RESEARCH METHOD}

This research used both qualitative and quantitative method. The primary data was obtained through interview and note-taking process. This research method involves the process of data collection (as well as transcription if required) and data analysis. This research is based on phenomenological philosophy. This paradigm suggests the research flow to use qualitative approaches. The data collection involves the citizen language use that cannot be obtained directly, due to the insignificant impact of the result to this community as the source data. Therefore, this research will refer to the respective speakers' community, through considering their mother tongue in that community.

The research will be conducted in Denpasar, where it will be classified into four regions of East, West, North, and South Denpasar. Several places will be pointed out in its intensity of multi-languages interactions, such as the marketplace, sports center, offices, etc. The further motive to sites chosen will be based upon the high number of Balinese language use and interaction among the speaker of any languages. In this place, we will enable the research to gather data that heterogenous in the form, but homogenous in its characteristics.

Data types in this research are oral and spoken data. The primary data in this research are language competence, choices, and maintenance that can be used by speakers of immigrant ethnics in Denpasar. This data will be classified into those three different frameworks and based upon the location of data collection. The total respondents are 50 people for every region, with a total of 200 respondents. The data collected are oral data on language attitude to Balinese language and written data on language competence to obtain an immediate result of language shift that can be analyzed from the bio-linguistics diversity point of view. The secondary data of this research involves a) sociolinguistics survey result and b) information on the current Balinese language, culture, and community tradition condition.

Several instruments used to gather data in this research are classified into primary and additional tools. The primary device in this research is the researcher, where it will eliminate the possibility of participation and observation method. Several instruments of data collection are triangulated to keep track of the scope of discussion in this research as well as keeping the validity and reliability of the data collected in this research Linguistics survey questionnaire is used for the additional instrument. List of 
questions is drafted in specific, concrete, and contextual assessment format. Several sources of the question list are modified for the sake of this research.

\section{FINDINGS AND DISCUSSION}

\section{A. Bio-Cultural Diversity in Denpasar}

Based on the data collected at Statistic Center Institution of Denpasar (https://denpasarkota.bps.go.id/), the data is classified into the number of population, religion, and village/ Banjar number in Denpasar. Based on the population number, the highest result is shown by Sesetan in South Denpasar, Sumerta Klod in East Denpasar, Pemecutan Klod in West Denpasar, and Ubung Kaja in North Denpasar. Furthermore, the data is based on religion number that shows the highest religion diversity in South and West Denpasar. Based on village/ Banjar number, the lowest number of a customary village is on Padang sambian, while the most depressed usual Banjar number is on Dauh Puri Kaja.

Population number can be related to the religion to provide a preliminary framework to the ethnic mapping. Furthermore, the number of customary villages and Banjar, as well as the official Banjar in particular regency, can affect the development of the respective ethnic. The preliminary framework to ethnic diversity number in every regency can generate three research focus. Those are: (1) the high population number in Sesetan, Sumerta Klod, Pemecutan Klod, and Ubung Kaja; (2) the high possibility of ethnic diversity in West and South Denpasar; and (3) the high possibility of ethnic development at Dauh Puri Kaja village.

After further observation, data gathered on the field shows a particular number of the immigrants in Denpasar. Based on the data acquired at all four regency offices in Denpasar, the village that holds the highest number of immigrants is its regency are Kesiman Kertalangu for East Denpasar regency, Padang sambian Kaja for West Denpasar regency, Sesetan for South Denpasar regency, and Ubung Kaja for North Denpasar regency. Through analyzing the data in these regencies, the comparison of population and immigrants that reflect its ethnic mapping shown as follow:

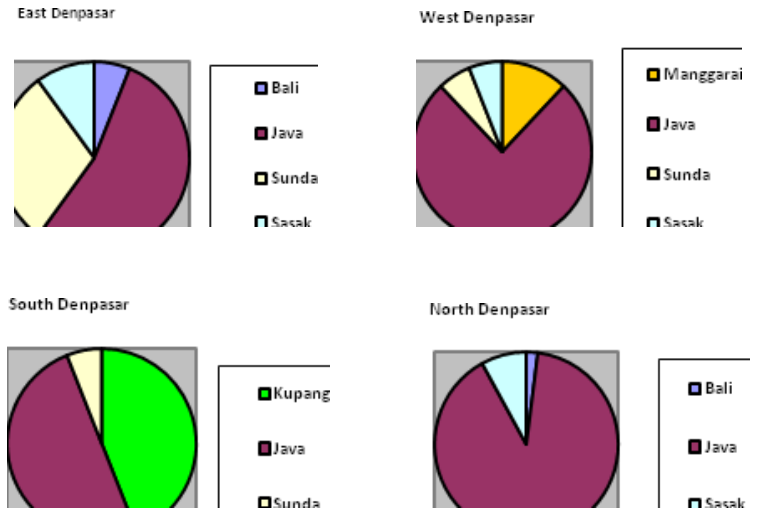

\section{A. 1. East Denpasar}

Geographically, East Denpasar is located next to Batubulan village, Sukawati district, Gianyar regency. This condition shows the effect of immigrants' language and culture to the Balinese style from Gianyar regency. According to its literature and ethnic diversity, the number of immigrants shows a high frequency of ethnic interaction. The apparent impact is the high number of immigrants on village located in the borderline of Gianyar regency; which is Kesiman Kertalangu village.

Following the data collected in the field, several points of ethnic interaction can be concluded from the number of immigrants in Kesiman Kertalangu village, is located in Tohpati community. Out of 50 respondents, the ethnic number spread shows that more than $50 \%$ of the immigrant ethnic majority is Javanese ethnic. Further mapping in the field revealed that around 3\% of the total respondents would also be taken into account in language diversity, since the respective respondents were born outside Bali and live long enough outside Bali to find various difficulties in Balinese language competence; the number is as much as the immigrant.

Several further mapping that can affect language diversity in this community is the diversity of occupation, where there are around 30\% the choice of profession is equally on private fields, entrepreneur, and other unspecified rule. Due to the average ranging from trade, the average age obtained is above 31 years old. This result affects Balinese language position as the majority of language in Denpasar, where some number of respondents chooses not to learn the Balinese language. As much as $74 \%$ of the respondents that decide not to learn the Balinese language implied a relationship between the low probability of language change around a particular range of age.

\section{A. 2. West Denpasar}

West Denpasar is located beside North Kuta district, Badung regency. This condition indicates the flow of immigrants and cultural as well as language influence from other community or even Balinese language in Kuta itself. Through similar data, it can be suggested that West Denpasar, where Padang sambian Kaja village can refer to the assumption that immigrants still prefer to stay on the border area to gain easier access from the center of the city to other places that potentially provide guaranteed occupation. This effect shows the relationship of a vast residential area with the potential of the profession to ethnic and language mapping.

Referring to the data collection in Padang sambian Kaja village, the highest level of ethnic interaction is around Swamandala neighborhood and the community around KeboIwa Street. In those neighborhoods, even with the majority of Javanese ethnic in $76 \%$ of the respondents, there are equal numbers of $5 \%$ of Sundanese and Sasaknese ethnic, as well as $10 \%$ of the other remaining ethnic. This identical result suggests that immigrants are well accepted in this community. 
Based on the environment condition and the potential of occupation in Padang sambian Kaja, there are $22 \%$ of respondents around 19-20 years old and around 25-26 years old. This result supports the high number of private fields that mostly depends on the tourism sector. 68\% of individual fields' workers also point out the majority of language choice; where $60 \%$ prefer to use the Indonesian language in their daily communication. This result implies the significant effort of Indonesian language maintenance, where $84 \%$ choose not to learn the Balinese language; even though this language is the majority language in Bali. Furthermore, this result is the highest number concerning the low effect towards majority language when compared to results of other regencies. Therefore, fields of occupation can give large impact to the language shift, where the regional majority language can be put aside as long as there is another language to help the speakers' communication in their corresponding occupation.

\section{A. 3. South Denpasar}

According to the location, South Denpasar is also located beside North Kuta district, Badung regency. Though regarding territory, South Denpasar is the most massive regency in Denpasar that covers Serangan Island and other notable locations, such as government offices, large area to be occupied by the immigrants, and the tremendous potential of occupation that located in several villages of Renon, Sanur, or Panjer. Based on the preliminary observation on the relationship of settlement vicinity and field of the rule, the high number of immigrants showed by Sesetan village that gained the most accessible access to the main street that connects every other town.

The high number of immigrants in Sesetan village is supported by results of data collection in three different interaction points in Pegok neighborhood, Settlement around the main street of Sesetan, and Gumuk Sari neighborhood. In contrast to other regions in Denpasar, the ethnic mapping shows there are $50 \%$ of Javanese ethnic and up to $47 \%$ of other ethnics aside from Sundanese and Sasaknese. This number suggests that high diversity in the community is not a direct result of the majority of immigrants' language, which in this case comes from Javanese ethnic.

A balanced result of ethnic mapping will provide several impacts to the language tolerance in this community. Even with $40 \%$ of the respondents are around 31 years old and that $64 \%$ of it works at private fields of occupation, only $20 \%$ of the total respondents that choose not to study the Balinese language. Up to $87 \%$ of the language acquisition is done through daily conversation that will not directly show their language choice since the result indicates that $80 \%$ respondent still use the Indonesian language in their everyday conversation. Therefore, language tolerance in this context refers to passive proficiency on the style.

\section{A. 4. North Denpasar}

Geographically, North Denpasar is located beside
Abiansemal district, Badung regency. To this matter, data observation on the field is justified further regarding the high number of immigrants from UbungKaja village. UbungKaja is the border village that separates Denpasar with other western places in Bali, such as Tabanan and Buleleng. Furthermore, Ubung village has a terminal that directly connects various trips to any regions outside Denpasar. Supported by the broad area of settlement, this village is another example where a high number of immigrants of different ethnics in the border area can be explained through looking at the relationship of settlement possibility and the potential of occupation.

In Ubung Kaja village, the highest level of ethnic interaction points out to a community around Kelapa Muda Street, Pemangkalan. In this neighborhood, data collected is the high number of Javanese ethnic as the immigrants' majority, which suggests different effect to the mapping in Sesetan village. Up to $90 \%$ Javanese ethnic of immigrants in this Ubung Kaja village will surely suggest direct impact to Balinese language shift in the future.

This high number of Javanese ethnic majority suggests direct impact to the language used in daily conversation, where $42 \%$ respondent; which is the highest number when compared to other regencies result in this term; uses their regional language. It is also in this context that the use of Balinese language is absent; whereas in another regency, at least there are $4 \%$ that will sometimes use the Balinese language as an impact of interaction to the majority of Balinese language speakers. The number of Junior High/High School students in $22 \%$ and $6 \%$ of the total respondents; which also the highest number when compared to other regency; gives an impact of the necessity to learn Balinese language, where 55\% is done through learning process during school years.

\section{B. Bio-Linguistic Diversity Mapping in Denpasar}

Based on the bio-cultural diversity mapping above, biolinguistics diversity can be measured by referring to language use, choice, and attitude obtained in the field. Through using this method, findings obtained suggest that language use in daily communication can be classified into the use of Indonesian language, Balinese language, the foreign language that refers to the English language. Besides, they also use native language; which further organized into the use of Javanese, Sundanese, Sasaknese, Manggarainese, and Kupangnese language. According to the speaker language proficiency, daily communication can reflect language choice and the majority of language use, while ethnic group mapping can suggest the effect on this speaker language attitude.

Bio-Linguistics diversity in four regions in Denpasar showed few different results. One of the results showed that more than $50 \%$ of the language used by the respondents in all regencies is in the Indonesian language. In contrast, even though North Denpasar showed no result to the use of Balinese language, all other three regencies explained $4 \%$ of the language use, which suggests the same number to 
native language use of another immigrant minority group. This number implies the effect of Balinese language to language choice and attitude of immigrant languages. This effect can be used as a base to establish the level of Balinese language maintenance and shift.
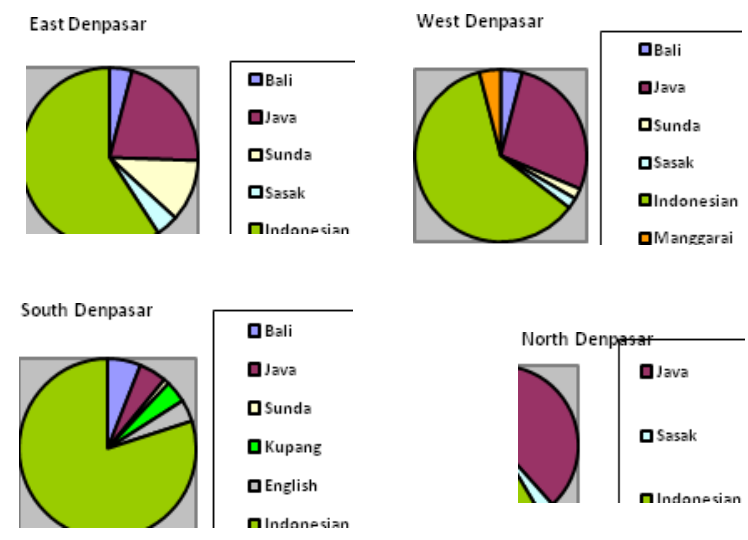

The mapping above shows that the highest level of biolinguistics diversity occur in South Denpasar regency, while the lowest one showed by North Denpasar. A relationship that can be concluded out of this result is the high number of bio-linguistics diversity in a particular community will also change the high level of Indonesian language use. This relationship will also reflect how Indonesian language in its national role can directly affect surrounding language maintenance and shift.

\section{Factors that affect Language Shift in Denpasar}

Data mapping can be done to measure Balinese language shift according to the bio-linguistics diversity of the immigrants, through using analysis result of language attitude, choice, use, and maintenance. Based on the data acquired in every region, the highest number of immigrants derived from Kesiman Kertalangu, Padang sambian Kaja, Sesetan, and Ubung Kaja village.
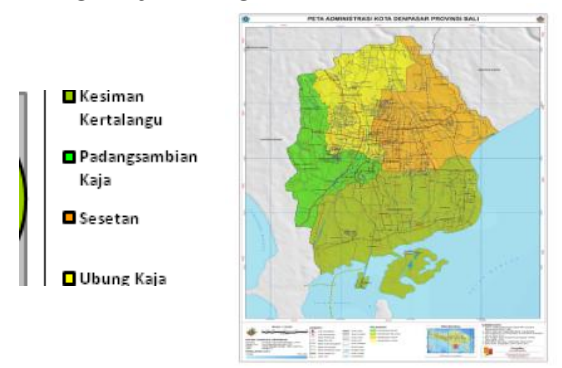

The relationship that can be seen from the map and number of immigrants is the effect of land size and the location of regency to bio-cultural diversity in the area; which in this case, East and South Denpasar are located along the east line of Bali. Data collected in each village showed that the majority of the immigrant ethnic group is Java, though more than $80 \%$ of the respondents stated that the language they have mastered is the Indonesian language; they do not directly imply that their mastery in language as the Javanese language to show their ethnic identity. In the case of language maintenance and shift, around $22 \%-51 \%$ stated that they wanted to master the Balinese language. The relationship that can be found is how high level of a global majority will affect the language attitude even to the context of a small community group that supposed to be dominated by other ethnic. In different context, language shift also occur with the same result, where the potential of field of occupation can give more significant impact to language choice; for example, in Padang sambian Kaja, $48 \%$ of the respondents said that they want to master foreign language (mainly English language) to help them in their occupation that mostly concerns tourism sector.

Along the language attitude result that showed an enormous impact of Balinese language as the majority language, respondents stated that the Indonesian language still regarded as the most useful language to use. This result is supported by the fact that response from the respondents will rise. It depends on the community of language use; for example, in the context of native regions, $50 \%$ of Indonesian language use will increase to $65 \%$ in Denpasar, $80 \%$ in Bali, and eventually reach more than $90 \%$ in any other regions in Indonesia. This result is also supported by the frequent use of Indonesian language in several domains; such as family (40\%-50\% of Indonesian language) and religious domain (64\%-68\% of Indonesian language). Both domains should have taken high impact of native language use, due to the strong influence of ethnic and personal characteristics.

Further response to language use can be seen through the immigrants' language attitude, where they observe around 18\%-34\% Balinese speakers use the Indonesian language in every regency, then rise into 50\%-76\% of Indonesian language use when seen in Denpasar. The significant benefit of Indonesian language in Denpasar; where more than $80 \%$ agreed in this case, produce an impact towards Balinese language shift as the majority in Denpasar. This impact is supported by the fact that only $50 \%$ of the respondents that think the Balinese language will be quite useful in their communication.

Through explicitly using the result of language attitude and choice, the communication between immigrants and Balinese people is mainly in the Balinese language (8\%$36 \%)$ or Indonesian language (54\%-94\%). Apart from the effect of language use context; where South Denpasar (Padang sambian Kaja) always has the highest number of Indonesian language use, as an impact of tourism condition and potential. This result comparison keeps rising along the size of language interaction context, where the highest number of Balinese language use is in Denpasar. In a different context, the number resulted in language choice of the immigrants ethnic are $22 \%-56 \%$ for the Javanese language (where in this case, Java is the majority immigrants' ethnic) and $10 \%-74 \%$ for the Indonesian language. Differences in the result of language choice reflect a significant potential for language shift, where the Javanese language can stand well to the Indonesian 
language when compared to how the Balinese language cope with the Indonesian language.

Balinese language maintenance can be seen through looking at several contexts, which one of them showed in the context of occupation. Not half of the respondents (32\%-44\%) stated that they need the Balinese language in their work. Even though this number rose to $56 \%$, when observed through the need of Balinese language in general context, only around $20 \%$ that stated they needed it. Another point of view that supports the factors in Balinese language maintenance is the immigrants' level of comprehension to this language. Various results obtained on the comprehension level to intonation and dialect in the Balinese language, where only $12 \%$ that fully understand the difference. This response is also aligned with their comprehension on the level of politeness and their ability in maintaining the flow of conversation, where less than $60 \%$ stated that they do not understand the difference in refinement and cannot manage the flow of communication in the Balinese language. By this result, the language attitude towards the Balinese language is still considered positive, since up to $64 \%$ agree that they need to learn these three aspects of intonation, dialect, and politeness. Furthermore, up to $76 \%$ are trying to utilize the Balinese language as their second language to be used in Denpasar.

Several other findings concerning Balinese language competence, which include terms, vocabularies, grammar, pronunciation, and speech level can be seen in detail; where comprehension regarding terms is still high up to $60 \%$ and up to on the speech level comprehension. In opposite to this result, when asked about the difference in vocabularies, grammar, and pronunciation, up to $82 \%$ of the respondent said that they do not understand it. Therefore, comprehension on the Balinese language can be described as a general and abstract concept in the speakers' cognitive ability in their multilingual community.

Regarding linguistics diversity, more than 50\% acknowledged that the Balinese language possesses several varieties in its form. Through further observation to the comparison on general use of Balinese language with its use in Denpasar, respondents stated that $68 \%$ of them do not realize any difference in the language. Around 50\% noted that the Balinese language used in Denpasar is as good as the one outside of Denpasar. This result is also supported by the minimum awareness to the Balinese language as the majority language in Denpasar, where $76 \%$ admitted their lack of knowledge by not knowing the position of majority language compared to other languages in Denpasar or to the Balinese language used in other regions in Bali.

Based on the results above, language attitude to the Balinese language in Denpasar can still be categorized as a positive attitude. Nevertheless, this Balinese language shift can be seen through looking at the change towards Javanese or Indonesian language, vulnerable Balinese language maintenance due to the existence of Indonesian language as national language, and the use of Indonesian language that can be accepted in the most context of intercultural language interaction. Inevitably and gradually, these three factors will decide Balinese language shift in Denpasar.

\section{CONCLUSION}

Bio-linguistics diversity mapping is a practical approach to deal with language shift when compared to the subjective findings resulted if the research done to the speakers themselves. Aside from the impact occurred on the relationship of diversity and maintenance, social, cultural aspects can provide a significant effect to language attitude that initiated from language choice, then followed to the process of language shift. In Denpasar, the results gained in this mapping are the relationship of Balinese, Javanese, and Indonesian language that signals the language shift towards the majority language. The existence of this majority language must be observed through the language use in particular context and the tendency of language attitude that based on every speaker's individual needs. Further research should be able to fully utilize this bio-linguistics diversity mapping to promote language shift as the foundation to reveal the process of language loss that occurs gradually to Balinese language speakers.

\section{REFERENCES}

[1] Abtahian, Maya R, et al.2016. Methods for Modeling Social Factors in Language Shift. University of Pennsylvania: Penn Libraries. http://repository.upenn.edu/cgi/viewcontent.cgi?article=1922\&conte $\mathrm{xt}=\mathrm{pwpl}$

[2] Bramono, Nurdin \& Mifta Rahman. 2012. Pergeserandan Pemertahanan Bahasa. Universitas Sebelas Maret Surakarta. http://download.portalgaruda.org/article.php?article=116515\&val=53 19

[3] Chaer, Abdul. 2004. Sosiolinguistik: Perkenalan Awal. Jakarta: PT RinekaCipta

[4] Chon, Abigail C \& Maya Ravindranath. 2014. Local Languages in Indonesia: Language Maintenance or Language Shift? Masyarakat Linguistik Indonesia: Volume 32, No.2. http://www.linguistikindonesia.org/images/files/2.pdf

[5] Cole, Michael and Sylvia Scribner. 1974. Culture and Thought. New York: John Wiley and Sons, Inc

[6] Croft, William. 2003. Social Evolution and Language Change. University of Manchester. https://www.unm.edu/ wcroft/Papers/SocLing.pdf

[7] Fasold, R. 1984. The Sociolinguistics of Society. Oxford: Basil Blackwell

[8] Fishman, J. A. (ed). 1968. Readings in the Sociology of Language. The Hague; Mouton

[9] Givon, Talmy. 2002. Bio-Linguistics. Linguistics: an Interdisciplinary Journal of the Language Sciences. docenti2.unior.it/doc_db/doc_obj_18094_01-022011_4d47fd1057de9.doc

[10] Grosjean, F. 1982. Life with Two Languages: An Introduction to Bilingualism. England: Harvard University Press.

[11] Grosjean, Francois\& Ping Li. 2013. The Psycholinguistics of Bilingualism. Oxford: Willey-Blackwell

[12] Holmes, Janet. 1992. An Introduction to Sociolinguistics. London: Longman

[13] Jendra, I Wayan. 2007. Sosiolinguistik: Teoridan Penerapannya. Surabaya: PenerbitParamita

[14] Kangas, Tove Skutnabb. 2004. On Biolinguistics Diversity - Linking Language, Culture, and (Traditional) Ecological Knowledge. Interdisciplinary seminar At the Limits of Language. www.helsinki.fi/hyy/skv/v/SkKangas_Madrid_March_2004_paper.doc 
[15] Khadidja, Ait Habbouche. 2013. Language Maintenance and Language Shift among Kabyle Speakers in Arabic Speaking Communities. Algeria: University of Oran. theses.univoran1.dz/document/TH3963.pdf

[16] Kovecses, Zoltan.2006. Language, Mind, and Culture. Oxford: Oxford University Press

[17] Malini, Ni LuhNyoman Seri. 2011. Dinamika Bahasa Bali di Daerah Transmigran di Provinsi Lampung. Disertasi. Universitas Udayana. Denpasar

[18] Manzini, Rita and Leonardo Savoia. 2007. (Bio) Linguistics Diversity. Biolinguistics: Language Evolution and Variation. UniversitàdegliStudi di Firenze. http://www.biolinguistics.uqam. ca/venice2007/Manzini_Savoia.pdf

[19] Masruddin. 2013. Influenced Factors towards the Language Shift Phenomenon of Wotunese. Kajian Linguistik dan Sastra: Vol 25, NO.2.

https://publikasiilmiah.ums.ac.id/bitstream/handle/11617/7438/5\%20 -\%20Masruddin.pdf?sequence $=1$

[20] Mueller, Franz. 2009. Language Shift on Java. The Linguistic Association of Canada and the United States: Lacus Forum 34. www.lacus.org/volumes/34/215_mueller_f.pdf

[21] Scollon, Ron, and Suzanne Wong Scollon. 2001. Intercultural Communication. Oxford: Blackwell Publisher

[22] Suastra, I Made dkk. 2016. Sikap Bahasa Penutur Sasak dan Sumbawa di Bali. Penelitian Grup Riset Hibah PNBP Universitas Udayana

[23] Tika, I Ketut dkk. 2015. Bahasa dan Kategori Sosial pada Masyarakat Bali, Sasak, dan Sumbawa: Sebuah Kajian Sosiolinguistik pada Rumpun Bahasa Bagian Timur MelayuPolinesia Barat. Penelitian Grup Riset Hibah PNBP UniversitasUdayana

[24] Wardhaugh, Ronald. 1986. An Introduction to Sociolinguistics. Oxford: Basil Blackwell

[25] Wertheim, Suzanne. 2003. Linguistic Purism, Language Shift, and Contact-induced Change in Tatar. Berkeley: University of California. http://escholarship.org/uc/item/3x61t12t\#page-1

[26] Winford, Donald. 2003. An Introduction to Contact Linguistics. Oxford: Blackwell Publishing 